\title{
A FÖLDRAJZI ÉS A KULTURÁLIS TÁVOLSÁG KAPCSOLATA - MILYEN MESSZE VAN VALÓJÁBAN A FERTŐDI ESTERHÁZY-KASTÉLY?
}

\author{
VIZI ISTVÁN GYÖRGY -KULCSÁR LÁSZLÓ-OBÁDOVICS CSILLA \\ THE CONNECTION BETWEEN GEOGRAPHICAL AND CULTURAL DISTANCES: \\ HOW FAR IS THE ESTERHÁZY PALACE OF FERTŐD IN REALITY?
}

\begin{abstract}
This study examines the rarely researched relationship between geographical distance (on-road time in minutes) and cultural distance (the cultural motivation measured by the ratio of graduates) in the case of visiting an attraction of heritage tourism. The tourist destination in question is the Esterházy Palace in Fertőd. The database is based upon the Hungarian tourists who visited the castle in 2016. Geographic accessibility was calculated on the postal zip code, and the cultural distance was estimated on the basis of the degree-owner (graduate) population of the examined districts. Based on our results, we determined, on the one hand, the types of the Castle visitors' starting geographic location and the social profile of different regions. On the other hand, we determined the role of cultural distance in the "crossing" of the geographical distance. Our results show that greater geographical distance is also associated with an increase in the significance of cultural distance in order to reach a heritage tourism target. Thus, the joint examination of geographic and social distance is of increased importance in the field of tourism research.
\end{abstract}

Keywords: Heritage tourism, cultural distance and geographical distance, visitors, social profile, Esterházy Palace, Fertőd, Hungary

\section{Bevezetés}

Tanulmányunk azt a kérdést vizsgálja, hogy milyen kapcsolatban van a földrajzi és a kulturális távolság egy örökségturisztikai objektum, jelen esetben a fertődi Esterházykastély látogatói körében. A kulturális távolság fogalmát a tanulmányban nem a szociológiában ismert és PARK, R. E. (1924), majd BogARDus, E. S. (1929) által bevezetett és módszertanilag is kialakított kategóriaként értelmezzük, azaz nem az egyes társadalmi csoportok közötti viszonyként, hanem egy jelenségtől, intézménytől való fizikai távolság kulturális értelmezéseként. Hasonlóképpen félreértésekre adhat okot az az általánosan ismert tény is, hogy az emberek társadalmi viszonyaikat jellemezve földrajzi, vagy a térbeliséget kifejező szavakat használnak: „közeli barátok vagyunk”, „távol álljon tőlem” stb. (Matthews, J. L.-MatLock, T. 2011). Tanulmányunk ennek zavaró hatására is szeretné felhívni a figyelmet.

A kérdésfeltevés önmagában is jelzi azt a szakirodalomból ismert nézetet, amely szerint a távolság nem egyszerúen fizikai mértékkel (hosszmérték vagy időmérték) mérhető csak, hanem ugyanolyan fontos annak percepciója, fontosak a kognitív jellegzetességei, hiszen míg valaki számára egy távolság közeli, addig ugyanaz másoknak távoli. Van, aki kulturális, életmódbeli, értékrendszerbeli jellegzetességéből adódóan egy kulturális örökséget képviselő desztinációt magától távolinak érez akkor is, ha az az elérhetőség szempontjából közel van, és természetesen a fordítottja is megfigyelhetô. Másképpen megfogalmazva mivel a fizikai távolság adott és nem változtatható (most hagyjuk figyelmen kívül azt, hogy a technika fejlődésével az elérhetőség persze változhat, de a változás nem gyakori), a kulturális távolság viszont társadalmi tényezőkhöz kötött, így adódik a kérdés: milyen 
kapcsolatban van a földrajzi és a kulturális távolság? Egy adott örökségturisztikai intézmény által megjelenített értékek, ismeretek vonzása mekkora földrajzi távolságot hidal át olyan emberek körében, akik hasonló értékekkel rendelkeznek? Felvethetô a kérdés másik oldala is: a kulturális távolság, mint „taszító” tényező hogyan „növeli meg” a távolságot, amely az elérhetőség szempontjából kicsi, fizikailag nagyon közel van?

\section{Kutatási elózmények}

A turizmus egyik központi kategóriája a távolság, a mozgás. RÁTz T.-VIZI I. (2007) ennek a mozgásnak számos típusát sorolják fel és arra is felhívják a figyelmet, hogy a turizmus és a mozgás, a távolság szorosan összefüggő fogalmak. A turizmus nyomást gyakorolhat például a közlekedési viszonyok fejlesztésére, a közlekedési viszonyok alakulása pedig befolyással van a turizmus fejlődésére. MichaLKó G. (2016) a távolságot relatív fogalomnak tartja, s ebbe a relativitásba nemcsak a természeti, fizikai tényezőket, hanem az attrakció kulturális összefüggéseit is beleérti. A földrajzi és a kulturális távolság egymáshoz kapcsolódó értelmezése tehát ígéretes, de nem kellően kutatott jelenség ma, annak ellenére, hogy többen már tágították a távolság csak fizikai fogalomként való értelmezését. KulCSÁR L.-OBÁDOVICS Cs. (2016) a távolság kérdésének a területi mobilitás és az emberi erőforrások összefüggésével való kapcsolatában kiemelték, hogy a mobilitásban nagy szerepet játszik a távolság kulturális értelmezésének megalapozottsága, vagyis az, hogy a mobilitási döntés során az emberek helyesen mérik-e fel saját humán erőforrásaikat és annak piaci értékét a választott helyen.

A szakirodalomban távolság értelmezésével kapcsolatban tehát jelentős változások következtek be az elmúlt évtizedekben. Az egyoldalú fizikai vagy gazdasági megközelítések mellett ennek a fogalomnak a társadalomtudományi értelmezése is egyre erőteljesebben megjelent. ANKOMAH, P. K-CROMPTON, J. L. (1992) már negyedszázada felvetették az úgynevezett kognitív távolság jelentőségét a turizmus kutatása területén. Véleményük szerint a távolság jelentőségét is elemző kutatások korábban elsősorban pénzügyi, fizikai és időbeli tényezők alapján ítélték meg annak fontosságát a turizmus területén. Pedig - mint rámutattak - a humán geográfiai írások már az 1950-es években felhívták a figyelmet a földrajzi és pszichológiai tényezők együttes kutatásának fontosságára. A turizmus területén ez a kapcsolat sokáig mostohán kezelt kutatási terület volt és bizonyos mértékben az ma is. Pedig - mint azt COOK, R. L.-MCCLEARLY, K. W. (1983) már igen korán megállapították - a turisták a távolságot jellemzőbben ítélik meg a kognitív tényezők, mint a fizikai tényezők (költség, idő, kilométer) alapján. Megfelelő motiváció esetén a turisták a fizikai távolságot általában alulbecsülik. A szakirodalomban ennek a kérdésfeltevésnek a vizsgálata igen ritkán fordul elő.

A távolság hatását a turisztikai döntésekre több tanulmány is elemezte, főként az országhatárokat átlépő utazások esetében. LYONS, S. et al. (2009) például megállapították az utazási távolság negatív hatását a látogatottságra, de a kulturális motiváción alapuló távolság fogalma náluk nem szerepelt a vizsgált változók között. NYAUPANE, G. P. et al (2004) a turisták által megtett távolságot elsősorban az életkorral és a jövedelemmel hozták összefüggésbe. WYNEN, J. (2013) felhívta a figyelmet a turisztikai kutatásokkal kapcsolatban az elérhetôség, illetve távolság, valamint a társadalmi-demográfiai változók együttes elemzésének hiányára az utazók döntéséire gyakorolt hatással kapcsolatban. Kérdésfeltevése az volt, hogy milyen tényezők határozzák meg az egynapos turisztikai célú utazásoknál a kiindulópont és a desztináció közötti távolság kapcsolatát. Úgy találta, hogy a fizikai tényezők - például az éghajlati, időjárási viszonyok - mellett a társadalmi tényezők - például a nem, az életkor, a gyerekek száma, valamint az iskolázottság - hatása volt szig- 
nifikáns. A magasabb szintû iskolázottság növelte az egynapos turisztikai célú utazások távolságát. Ez az eredmény már felveti azt a kérdést, hogy az iskolai végzettségnek vajon Magyarországon is van-e távolságot áthidaló szerepe?

NiCOLAU, J. L.-MÁs, F. J. (2006) a távolság tényezőjét és az árak hatását vizsgálták az utazási döntések alakulására. A kulturális motiváció hatását abban látták, hogy a desztináció kulturális vonzereje csökkenti az árak negatív befolyásoló erejét. Megközelítésük hasonló a mienkéhez annyiban, hogy láttatja az úgynevezett ,puha” tényezők utazási döntést befolyásoló szerepét. Tanulmányukban a kultúra, mint kontroll változó alkalmazásával rávilágítanak az olcsó-drága fogalompár relatív jellegére: arra tehát, hogy egy utazás, egy kulturális örökség megtekintése olcsó-e vagy drága, azt nemcsak az ár, hanem a kulturális értékek is döntóen befolyásolják. MassarA, F.-SEVERINO, F. (2013) az úgynevezett pszichológiai távolság hatását elemezték az örökségturizmushoz kapcsolódó desztinációk és a kiindulópont közötti térbeli távolság ,áthidalásával” kapcsolatosan, amelynek az eredmények alapján közbülső (mediátor) hatást tulajdonított. A pszichológiai távolság és a kulturális motiváció erős összefüggését jelezték BODROGAI L.et al. (2017) is, megerősítve a társadalmi tényezők, a kulturális motiváció összefüggését az örökségturizmus területével. A kulturális távolságot FAN, D. X. F. et al. (2016) három jellemzővel határozták meg: az egyik a kultúrának tulajdonított jelentőség általában, a másikat a különböző magatartási jellegzetességek adták, míg harmadikként a társadalmi jellegzetességeket, mint például az iskolai végzettség említették. Ez utóbbi tényező hatását elemeztük mi is tanulmányunkban, feltételezve, hogy a kulturális érdeklődés és motiváció az iskolai végzettséggel változik, mégpedig úgy, hogy a végzettség emelkedésével annak fontossága növekszik.

\section{Elméleti és módszertani alapvetések}

Kutatásunk alapvetôen arra irányult, hogy bemutassuk az örökségturizmus területén értelmezhetô távolságfogalom földrajzi és kulturális megfogalmazásának összefüggését. Az Esterházy-kastély, amelyet az örökségturizmus vizsgálati desztinációjaként értelmeztünk, Magyarország nyugati végében, a Fertő tótól délkeletre, Fertőd városában, Eszterháza és Süttör településrészek között található. A kastélyt nemcsak az Esterházy hercegi család története, tevékenysége teszi híressé, hanem kivételes fekvése, nagysága, építészete és múvészi berendezése. Európa harmadik legnagyobb barokk-rokokó kastélya (Versailles és Schönbrunn mögött) kivételes múvészi és egyben politikai vonzást is gyakorolt fénykorában, Mária Terézia (1740-1780) uralkodása idején. A jelenlegi országhatár menti perifériális elhelyezkedése alkalmas annak vizsgálatára, hogy a kulturális szint által befolyásolt távolságfogalom hogyan függ össze a földrajzi távolsággal, másképpen fogalmazva hogy a kulturális szint milyen fizikai távolságot hidal át és milyen távolságot már nem.

Az általunk alkalmazott elméleti modell lényegét tekintve négy típust tartalmaz, amelyet két változó mentén alakítottunk ki. Az egyik változó a földrajzi távolság, közúton mérve, menetidőben (perc), a másik változó pedig a kulturális távolságot méri, amelyet a diplomások arányával szemléltetünk (1. táblázat).

A közeli-közeli típusnál nem kell különösebb erőfeszítés ahhoz, hogy a földrajzi távolságot áthidalják, mivel a távolság nem lényeges. A közeli-távoli típusnál ilyen erőfeszítésre szintén nincs szükség, de a kulturális motiváltság is hiányzik. A távoli-távoli típus témánk szempontjából csekély jelentôségú, a kastélylátogatás valószínúen ritka és esetleges, és ha el is jut a kastélyig egy ilyen típusú látogató, mert társasutazásában annak megtekintése szerepel, akkor többnyire megállapodik a kastély melletti étteremben, kocsmában, vagy csak a kastély parkjában tesz sétát. Az igazán érdekes típus a földrajzi elérhetóség szempontjából távo- 
A földrajzi és a kulturális távolság modellje (a szerzők szerkesztése)

Model of the geographical and cultural distances (ed. by the authors)

\section{Földrajzi távolság, elérhetóség}

Közeli

(az átlagnál rövidebb idő)

Távoli

(az átlagnál hosszabb idő)

\section{Kulturális távolság}

Közeli

(az átlagnál magasabb

a diplomások aránya)

Kulturálisan erôsen motivált

látogató, a látogatás plusz

erőfeszítést nem igényel

Kulturálisan erősen motivált, a földrajzi távolságot ,átlépő” látogató

linak, a kulturális távolság szempontjából pedig közelinek tekinthetố típus. Itt van jelentôsége annak, hogy a két típus különválikés a kulturális közelség áthidalja a földrajzi távolságot.

Az Esterházy-kastélyt 2016-ban összesen 77435 látogató kereste fel. A látogatók (beleértve az egyéni és csoportos látogatókat is) közül 65554 fó, azaz a látogatók 84,65\%-a adta meg a postai irányítószámát, közülük 54157 fő volt egyéni látogató (42 334 belföldi és 11823 külföldi). A látogatói jegyrendszer tekintetében a családos belépőjegyet igénybevevők száma került rögzítésre a postai irányítószám megadásakor, tehát a látogatószám nem a belépőjegyszámot jelenti. A regisztrált külföldi látogatók 38 országból érkeztek és az összes regisztrált látogatónak $21 \%$-át jelentették. A külföldi látogatók közül a legtöbben Ausztriából (20,5\%) és Németországból $(20,1 \%)$ érkeztek. Jelentősebb volt még a szlovák $(16,5 \%)$, a cseh $(9,7 \%)$ és az olasz $(5,2 \%)$ látogatók aránya.

A vizsgálat adatbázisa tehát a kastélyt 2016-ban felkereső 42334 egyéni magyar látogató postai irányítószáma volt. A budapesti egyéni látogatókat (9755fó) nem vontuk be a vizsgálatba, mivel egyrészt torzította volna az arányokat, másrészt az egyes kerületeknél a távolság dimenziója úgysem lett volna értelmezhető. (Ezt az elemzést majd külön szeretnénk publikálni.) Az irányítószám segítségével azonosítottuk a járásokat, mint kiindulópontot, meghatározva, hogy egy-egy járásból hányan keresték fel a kastélyt. A járási szintű aggregációt módszertanilag két körülmény tette szükségessé. Az egyik az volt, hogy a települések egy részénél csak néhány látogató volt regisztrálva (796 település esetében a látogatók száma nem érte el a tíz fót), továbbá a vizsgálatba bevont látogatók összesen 1269 településről származtak, így komolyabb statisztikai elemzés nehézkesebb lett volna. A másik ok pedig az volt, hogy a látogatóknál nem rögzítették az iskolai végzettséget, így az adott járás iskolai végzettség szerinti megoszlását vettük figyelembe. Tisztában vagyunk azzal, hogy önmagában az a körülmény, hogy egy járásban sok a magas iskolai végzettségú lakos, nem jelenti azt, hogy biztos, hogy azok látogattak el az Esterházy-kastélyba. Ha BABBIE, E. (1995) által megfogalmazott ökológiai tévkövetkeztetés esete forogna fent, akkor extrém esetben az is feltételezhető lenne, hogy bár a járás átlagos iskolai végzettségi szintje magas, a látogatók mégis az alacsony végzettségúek csoportjából kerültek ki; de azért valószínúsíthető, hogy az adott járásban lévő magas iskolázottságúak aránya jól előrejelzi a látogatottság szintjét.

Az egyes járások esetében a járásközpont és a kastély távolságát vettük alapul. Kétféle távolságot számoltunk ki a Google térkép segítségével: (1) a járásközpont és a kastély távolságát a legrövidebb úton, kilométerben és (2) a járásközpont és a kastély közötti távolságot időben, forgalom nélkül (perc). Ez utóbbit tartottuk meg, mivel más változókkal szignifikánsabb összefüggést kaptunk, mint a kilométerben mért távolság esetében. 
Elemzésünkben a következő alapváltozók szerepeltek:

- a járások (174) területi elhelyezkedése;

- a járásközpont és a kastély közötti közúti távolság, percben (forgalom figyelembe vétele nélkül);

- az adott járásból érkező látogatók száma a járás 7 évesnél idősebb népességéhez viszonyítva, tízezer fơre számolva;

- az adott járásban a 7 éves és idősebb népességben a diplomások aránya (az életkori megszorítás azt tette lehetővé, hogy mérsékeljük az eltérő termékenységú népesség témánk szempontjából torzító hatását);

- és az egy főre jutó jövedelem a járásban (2016).

A kutatásunk módszertani - és a jövőben végzendő kutatások továbbfejlesztési - lehetőségeit illetően bővebb és alaposabban megszerkesztett adatfelvételre van szükségünk, hogy egy újabb vizsgálatban az itt felvetett kérdéseket újra elemezzük, s más desztinációknál is alkalmazzuk a megbízhatóbb mérési módszereket. Továbbá WYNEN, J. (2013) alapján - aki arra is rámutatott, hogy az egynapos utazások tervezésénél az emberek kockázatcsökkentő tényezőket keresnek, amelyek ellensúlyozzák a kulturális motivációjú céllal kapcsolatos utazás esetleges csalódásait, vagy egyszerúen csak az ott töltött időt - joggal feltételezhetjük, hogy esetünkben is jelen lehet ilyen kockázatkerülő magatartás, amelyet többek között úgy valósíthatnak meg az utazók, hogy nem egyetlen kulturális desztináció a céljuk, hanem más igényeik (vásárlás, pihenés, egészségügyi szolgáltatások stb.) kielégítését is számba veszik. Ezt a megközelítést azonban jelenleg adatok hiányában még nem tudjuk vizsgálni.

Összességében azt mondhatjuk, hogy meglátásunk szerint ígéretes kutatási megközelítést vetettünk fel, amely ugyan további pontosításra szorul, de meggyőződésünk, hogy a következőkben ismertetésre kerülő eredmények kellően indokolják véleményünket.

\section{Eredmények}

Elsőként azt mutatjuk meg, hogy a földrajzi távolság (a kastély elérhetôsége közúton percben kifejezve) milyen térképi ábrázolást jelenít meg. Ez a térkép (1.ábra) nem tartalmaz adatot a látogatottságról, csak azt érzékelteti, hogy potenciálisan mennyi időbe kerülne az ott lakóknak az Esterházy-kastélyhoz közúton eljutni.

A térkép alapján látható, hogy az elérhetőség nem egyszerúen a sokszor emlegetett nyugat-kelet fejlődési irányt jelöli (Kulcsár L. 2017), ugyanis ha leszámítjuk Budapest kiváló közlekedési lehetőségeit, a kastély körül mintegy félkörben helyezkednek el az egyes kategóriák. Azaz nemcsak az Északkeleti régió, hanem a Délnyugati régió is hátrányosabb helyzetben van a kastély elérhetősége szempontjából.

Az egyszerú elérhetôségi különbségek nem tartalmaznak különösebb meglepetést. A Fertő elérhetősége a romániai és az ukrajnai határtól, vagy a Dráva partjától elég távolinak tűnik. A kérdés az, hogy a földrajzi távolság összefüggésben van-e, és ha igen, milyen mértékben a kastély látogatottságával. Ha a 2. ábra térképét szemügyre vesszük, azt láthatjuk, hogy a látogatók 10000 (hétéves és idősebb) főre számított gyakorisága összefügg ugyan a földrajzi elérhetôséggel, de ez az összefüggés nem egyértelmú.

A térképen a sötétebb szín a látogatók eloszlásának mértékét, másképpen szólva a települések közötti koncentrálódás szintjét jelzi: minél sötétebb a szín, annál több településból érkeztek a látogatók az adott járást tekintve. Az oszlopok magassága a látogatók 100007 éves és idősebb népességre jutó számát jelzi. Vannak olyan járások, amelyek földrajzi szempontból a távolabbi kategóriába esnek, a Kastély látogatottsága viszont szinte az összes települést érinti a járásban. Több tényező is okozhatja ezt az eredményt. Egyrészt lehetséges, hogy 


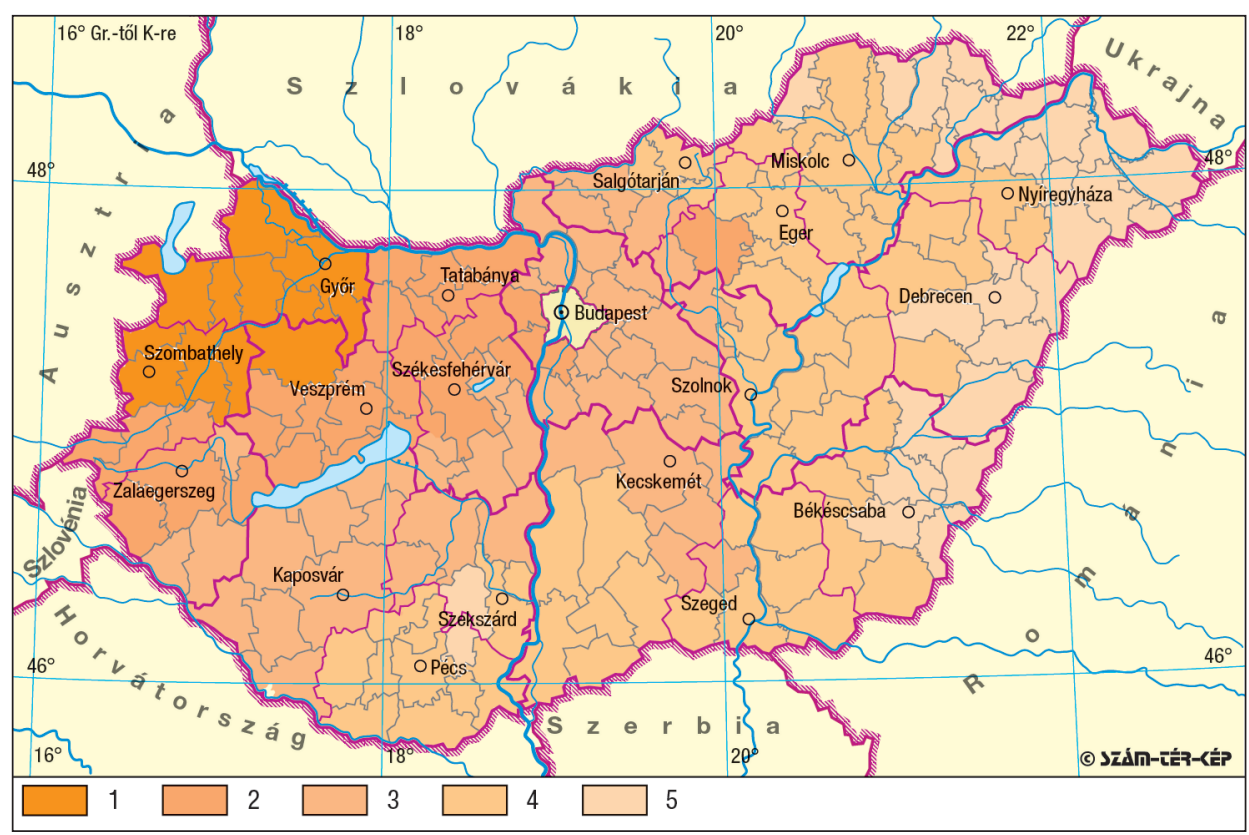

1. ábra Az Esterházy-kastély földrajzi elérhetősége (szerk. BоттLık Zs.). Jelmagyarázat: 1 - nagyon távoli járások; négy óránál több elérhetőségi idő; 2 - távoli járások; három és négy óra közötti elérhetôségi idő;

3 - közepes távolságú járások; két és három óra közötti elérhetőségi idő; 4 - közeli járások; egy és két óra közötti elérhetőségi idő; 5 - nagyon közeli járások; legfeljebb egy óra elérhetőségi idő;

Figure 1 Geographical accessibility of the Esterházy Palace (ed. by BотTLIK, Zs.). Legend: 1 - very distant districts (access time is more than four hours); 2 - distant districts (access time is between three and four hours);

3 - mid-range districts (access time is between two and three hours); 4 - nearby districts (access time is between one and two hours); 5 - very near districts (at most one hour's access time)

a néhány távolabbi járásban intenzívebb turisztikai mozgás indult meg a Sopron felé vezető úton (Sopron-Ausztria), s közbülső megállóként megnézték a kastélyt, vagy a Fertő tó vidékére irányuló turizmus egyik ajánlott időtöltése lehetett a Kastély megtekintése. De az is lehetséges, hogy a magasabb kulturális motivációjú turisták a járás több településén kifejezetten a Kastélyt és más kulturális örökség turisztikai attrakcióit keresték. A fentiek közül bármelyik, vagy azok kombinációja is lehetséges. Mindenesetre a 3. ábra jelzései felvetik a földrajzi és a kulturális távolság kapcsolatának kérdését. Elemzésünk következő lépése ennek megfelelően az lehet, hogy megvizsgáljuk az elérhetőség és a társadalmi profil kapcsolatát.

A földrajzi és a kulturális távolság nem független az adott távolságtípusok társadalmi-gazdasági profiljának sajátosságaitól. A 4. ábrán három változó alakulását láthatjuk az elérhetőség csoportjai mentén; az összehasonlíthatóság kedvéért mindhárom változó standardizált értékeit vetjük össze. Az ábrán látható, hogy a társadalmi-gazdasági profil az elérhetőség romlásával különböző mértékben ugyan, de egyre negatívabb adatokat mutat. A látogatók gyakorisága határozottan csökken az elérhetőségi idő növekedésével. Az életszínvonal 1 fớre jutó jövedelemmel jelzett mutatójának romlása is szembetúnő, minél távolabb kerülünk a nyugati határszéltôl, illetőleg Budapesttől. A diplomások aránya viszont sokkal kiegyenlítettebb képet mutat: a közepes távolságban lévő járásoktól mutat csökkenő tendenciát, de nem olyan mértékben, mint a jövedelem vagy a látogatottság.

A kiinduló kérdésfeltevésünket - a két típusú távolság viszonyát - vizsgálva LEE, E. (1966) migrációs elméletét alkalmazzuk, miszerint a migráció esetében alapvetően fontos 


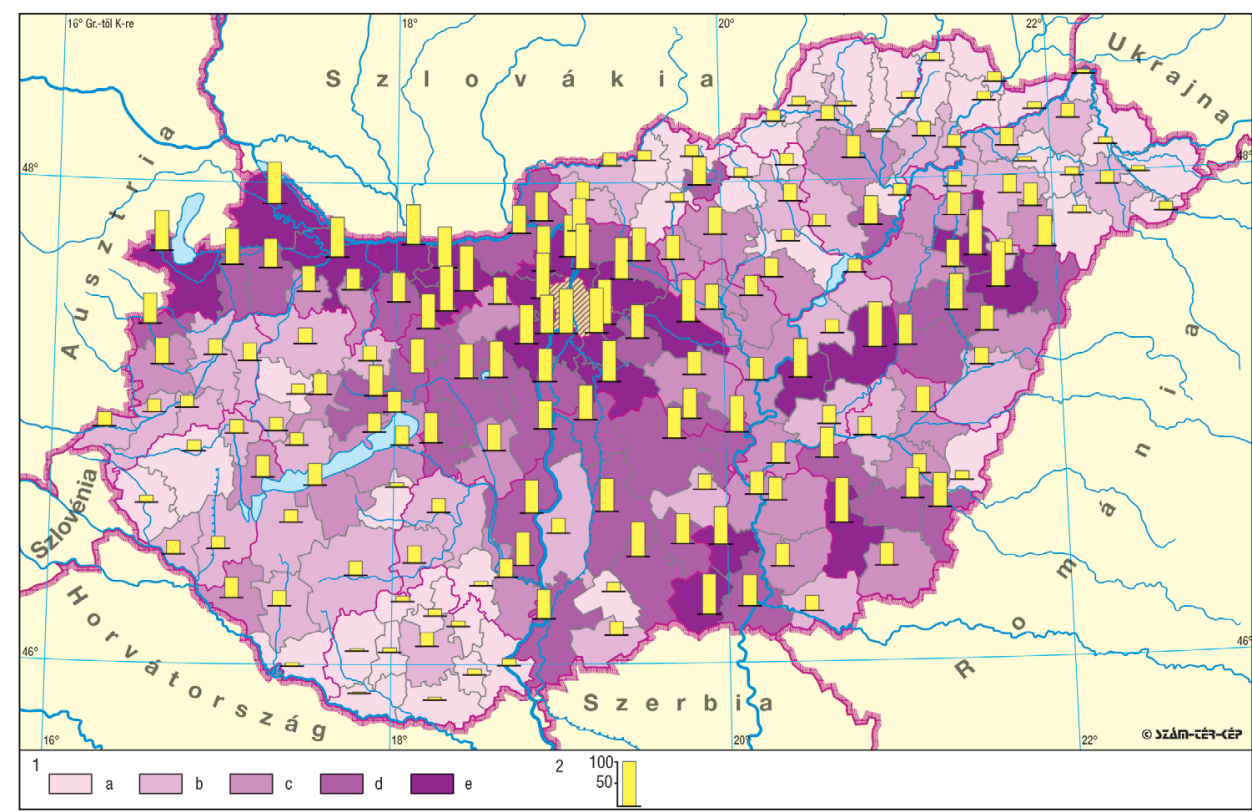

2. ábra Az Esterházy-kastély látogatóinak gyakorisága és a látogatók eloszlása a járás települései között (szerk. BOTTLIK Zs.). Jelmagyarázat: 1 - (a) A járás településeinek 0-19,9\%-ból volt látogató (nagyon alacsony érintettség),

(b) A járás településeinek 20-39,5\%-ból volt látogató (alacsony érintettség), (c) A járás településeinek 39,6-59,5\%-ból volt látogató (közepes érintettség), (d) A járás településeinek 59,6-79,5\%-ból volt látogató (magas érintettség),

(e) A járás településeinek 79,6-100\%-ból volt látogató (nagyon magas érintettség); 2 - gyakoriság: az oszlopok magassága a látogatók 10000 hétéves és idősebb népességre jutó arányát jelzi.

Figure 2 Frequency of visitors (columns) and distribution between the settlements in the district (ed. by BotTLIK, Zs.). Legend: 1 - (a) Visitors came from very few settlements in the district, (b) Visitors came from a few settlements in the district, (c) The visitors came from the medium part of the district's settlements, (d) The visitors came from the large part

of the district's settlements, (e) The visitors came from the very large part of the district's settlements; 2 - frequency:

The height of the columns indicates the ratio of visitors in the population aged 7 years and over, per 10000 people.

az úgynevezett közbülső akadályok leküzdése, amelyek a taszító (push) és a vonzó (pull) tényezők között mutatkoznak. Ezt a meglátást központi jelentőségúnek és kis változtatással alkalmazhatónak is tartunk. A kiinduló pont és a cél egyértelmú, a vándorlást pedig a látogatással helyettesítjük. A vonzó tényezőt az Esterházy-kastély által megjelenített örökségturisztikai érték jelenti, a taszító - esetünkben inkább „készteto”” - faktort pedig a kulturális motiváció, kulturális szint, amelyet, mint említettük korábban, a diplomások arányával mértük. Témánk esetében a távolság a közbülső akadály, s mivel annak járásonkénti mértéke az egyes elérhetőségi típusokban állandónak tekinthető, a közbülső akadály átlépéséhez a kulturális távolság „mértéke” nyújthat segítséget. Másképpen fogalmazva azt vizsgáljuk, hogy a kulturális távolság támogatásával milyen arányban tudják átlépni a közbülső akadályokat a különböző földrajzi távolságban élők. Azt feltételezzük, hogy ez az arány az egyes távolságoktól függően változik, s azt is feltételezzük, hogy minél közelebb van a turisztikai célpont fizikailag a lakóhelyhez, annál kisebb lesz a kulturális távolság szerepe.

A 4.ábra adatai alátámasztják ezt a feltételezést, mivel látható, hogy a közepes és távolabbi térségekben a látogatók azon járások esetében gyakoribbak, amelyekben az átlagnál magasabb a diplomások aránya. Az is látható az ábrában, hogy a nagyon közeli és a közeli járásokat illetően a kulturális távolság nem befolyásolta a látogatottság mértékét, mivel esetükben lényegében azonos a látogatók aránya, akár alacsony a kulturális szint (azaz a diplomások aránya átlag alatti), akár magas (a diplomások aránya átlag feletti). Más 


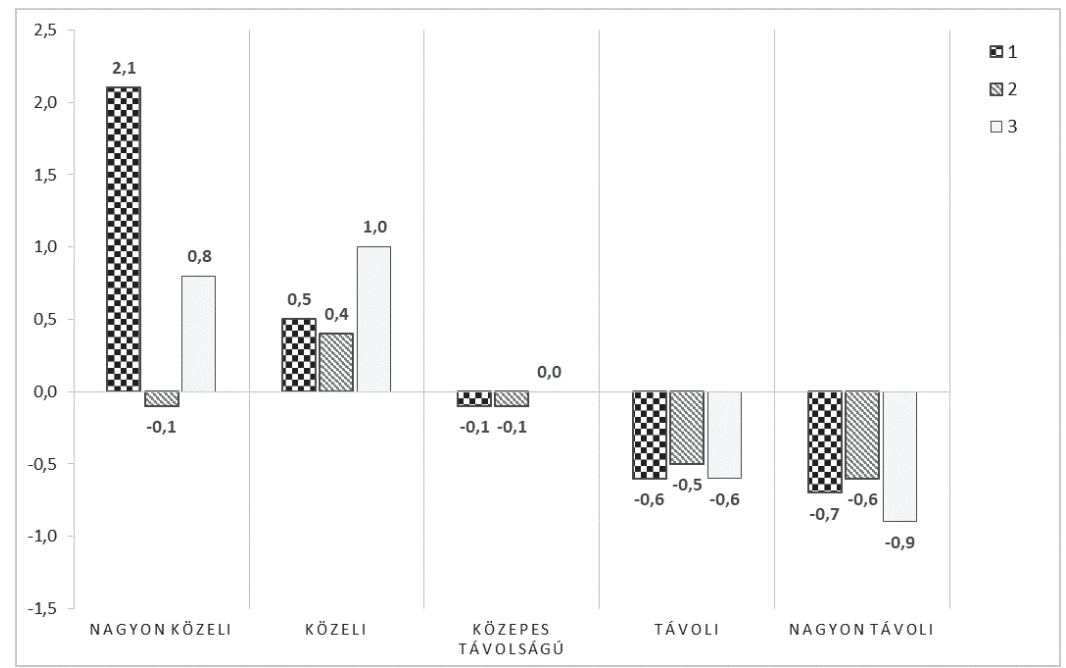

3. ábra Az elérhetőség mentén tipizált járások társadalmi-gazdasági profiljának néhány jellemzője (standardizált értékek). Jelmagyarázat: 1 - Látogatók száma 10000 hétévesnél idősebb lakosra;

2 - Diplomások száma 10000 hétévesnél idősebb lakosra; 3 - Egy főre jutó jövedelem, 2016

Figure 3 Some features of the socio-economic profile of the districts typified along with accessibility (standardized values). Legend: 1 - Number of visitors per 10,000 seven years or older inhabitants;

2 - Number of graduates per 10,000 seven years or older inhabitants; 3 - Per capita income, 2016

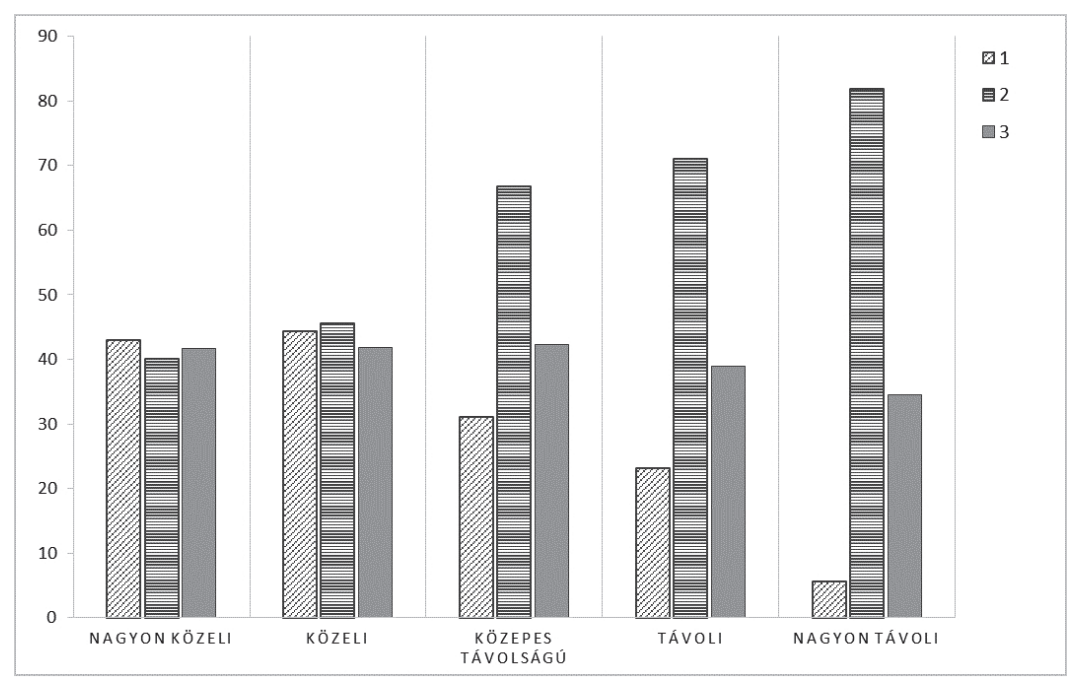

4. ábra A földrajzi távolságot „átlépő” kastélylátogatók aránya (3 - összesen) 1- az átlagnál magasabb és 2 - az átlagnál alacsonyabb kulturális színvonalú (diplomás) népességgel bíró járások esetében a földrajzi távolság csoportosítása szerint

Figure 4 Rate of the Palace visitors (3 - total) "crossing" geographic distance in case of certain districts having population (graduate population) with cultural standard 1 - higher and 2 - lower than the average, according to the grouping of the geographical distance

szóval ez azt jelenti, hogy ilyen közeli földrajzi távolságban a kastélytól kisebb kulturális távolsággal rendelkezők (a magas iskolai végzettségúek) szinte azonos arányban találhatók a látogatók között, mint a kevésbé iskolázott másik csoport. 
Ez a helyzet azonban megváltozik a földrajzi távolság növekedésével. A látogatók egyre nagyobb arányban kerülnek ki azokból a járásokból, amelyek közepes mértékú, vagy annál nagyobb földrajzi (elérhetőségi) távolságban vannak ugyan a kastélytól, de a kulturális távolságuk (a magasabb diplomával rendelkezők aránya) lényegesen kisebb. Az eltérés minden esetben szignifikáns, közepes távolságú járásoknál 0,050, távoli járásoknál 0,001 és a nagyon távoli járásoknál 0,000. Ez azt jelenti, hogy - LEE kategóriájával élve a fizikai (elérhetőségi) távolság növekedésével a kulturális távolság jelentősége nő. Minél inkább távol van földrajzilag egy járás a kastélytól, annál nagyobb a szerepe a kulturális szintnek, amely ,áthidalhatja” a földrajzi távolságot és emelheti a látogatottság arányát a közepes távolságú, a távoli és nagyon távoli járások esetében.

Azt mondhatjuk tehát, hogy ugyan a földrajzi távolság növekedésével csökken a kastélyt látogatók aránya, de ha a kulturális távolság ellentétesen mozog a földrajzi távolsággal, akkor a kulturális távolság szignifikáns mértékben befolyásolja a látogatottságot.

Ezt az összefüggést összevetettük az egy fơre jutó jövedelem változójával, s azt kell mondanunk, hogy a jövedelem eloszlása majdnem minden elérhetőségi típus esetében gyengítette a látogatottság és a diplomások aránya között meglévő összefüggést. A kulturális távolság látogatást ösztönző hatása csak a közepes távolságú járások esetében maradt majdnem szignifikáns, de a korreláció értéke valamelyest csökkent ott is: a korreláció, illetve a szignifikanciaérték a jövedelem hatásának kiszúrése előtt 0,444 - 0,002, a jövedelem hatásának kiszúrése után pedig 0,393 - 0,090. A jövedelemszint tehát komoly befolyást gyakorol a látogatottságra, és nemcsak a kulturális szinten keresztül, hanem a távolsághoz kapcsolódó költségtényezőkön keresztül is. Ennek az összetett befolyásoló tényezőnek alaposabb feltárása szintén az elkövetkező vizsgálatok feladata. A nagyon közeli és közeli kategóriában, ahogy az várható is volt, a parciális korreláció számítása sem hozott szignifikáns eredményeket, tehát a jövedelem szintje sem gyakorolt hatást a látogatottságra.

Megfontolandó viszont az az eredményünk, hogy a nagyon távoli elérhetőségi típusnál a jövedelemszint standardizálása a korábbi erős szignifikáns pozitív összefüggést a kulturális távolság és a látogatottság között szinte teljesen eltüntette. Feltételezzük, hogy e két tényező együttesen viszont szignifikánsan jelzi előre a kastély látogatottságát a nagyon távoli járások esetében. Adataink igazolják is ezt az összefüggést, mivel a jövedelemszint és a kulturális távolság együttesen jelentősen hat a látogatottsági szintre: a regressziószámítás eredményei alapján a korrelációs együttható 0,715, a szignifikanciaszint pedig 0,000 (2. táblázat).

2. táblázat-Table 2

A kulturális távolság és az egy főre jutó jövedelem (2016) együttes hatása a látogatottságra a lineáris regresszió számítása alapján

The combined impact of cultural distance and per capita income (2016) on the number of the visitors based on linear regression calculation

\begin{tabular}{lccccc}
\hline $\begin{array}{l}\text { Földrajzi távol- } \\
\text { ság (közúton való } \\
\text { elérhetóség) típusai }\end{array}$ & $\begin{array}{c}\text { Korrelációs } \\
\text { együttható }\end{array}$ & $\begin{array}{c}\mathbf{R}^{2} \text { értéke } \\
(\%)\end{array}$ & $\begin{array}{c}\mathbf{R}^{2} \text { korrigált } \\
\text { értéke (\%) }\end{array}$ & $\begin{array}{c}\text { A szignifi- } \\
\text { kancia szintje }\end{array}$ & $\begin{array}{c}\text { A járások } \\
\text { Száma }\end{array}$ \\
\hline Nagyon közeli & 0,671 & 45,1 & 32,9 & 0,067 & 12 \\
Közeli & 0,189 & 3,6 & $-3,8$ & 0,623 & 29 \\
Közepes & 0,474 & 22,5 & 18,7 & 0,005 & 44 \\
Távoli & 0,281 & 7,9 & 4,6 & 0,097 & 60 \\
Nagyon távoli & 0,715 & 51,1 & 47,3 & 0,000 & 29 \\
Együttesen & 0,441 & 19,4 & 18,5 & 0,000 & 174 \\
\hline
\end{tabular}


A nagyon távoli járások esetében a jövedelem tehát a kulturális távolsággal együtt jelentősen befolyásolja a látogatottság alakulását. Ebben valószínúleg a közlekedési költségek is szerepet játszanak. A nagyon közeli és közeli járásoknál a kulturális távolságnak és a jövedelemnek nem mutatható ki szignifikáns kapcsolata a látogatottsággal. Ezekben a járásokban a regresszióelemzés tanulságai szerint a jövedelem magas negatív, a kulturális távolság magas pozitív együtthatói egyszerre vannak jelen. A közepes távolságú és a távoli járások esetében a kulturális távolság regressziós együtthatója igen magas értéket kapott, a jövedelemé viszont alacsony és negatív értékkel szerepelt. Látható tehát, hogy a kulturális távolság ennél a két típusnál erőteljesebb, ugyanakkor a közepes távolság típusnál az eredmény szignifikánsnak bizonyul: a korrelációs együttható 0,474 , a szignifikanciaszint pedig 0,005 .

\section{Összefoglalás}

Tanulmányunk célja az volt, hogy felvessünk egy hazai viszonyok között nem kutatott, de a nemzetközi szakirodalomban is ritka kérdést a távolság fogalmának többféle értelmezhetőségéről a turisztikai kutatások területén. A földrajzi és a kulturális távolság összefüggését vizsgálva eredményeink rámutattak arra, hogy a kulturális távolság jelentősen befolyásolja a potenciális látogatók döntését, méghozzá főként a földrajzi szempontból távolabb eső régiókban. A jövedelem színvonala ennél a földrajzi távolság kategóriánál jelentős mértékben segíti a kulturális távolság pozitív hatásának érvényesülését. Eredményeink arra is felhívják a figyelmet, hogy a turizmus szektor szakembereinek és a szektorpolitika képviselőinek az eddigieknél sokkal nagyobb jelentőséget kell tulajdonítaniuk a kulturális távolság kategóriájának és befolyásoló szerepének. Szükségesek tehát azok a vizsgálatok, amelyek részletesebben feltárják ennek a tényezőnek hatását szoros kapcsolatban a turizmus földrajz korábbi megállapításaival, eredményeivel. Vizsgálataink adatait és eredményeit a vezetôi, menedzsmenti, tulajdonosi hierarchiában számtalan megközelítésből lehet elemezni, vizsgálni, feldolgozni. A kulturális távolság és a fizikai távolság összefüggésének a tanulmányban elemzett újszerú megközelítése új perspektívát nyit a turisztikai szektorban a gyakorlati, illetve az üzleti életben való alkalmazáshoz.

\section{Köszönetnyilvánítás}

A szerzők köszönik BoTTLIK ZsolT jelentős segítségét és kartográfiai munkáját.

\section{VIZI ISTVÁN GYÖRGY}

Soproni Egyetem Közgazdaságtudományi Kar, Sopron

vizi.istvan065@gmail.com

KULCSÁR LÁSZLÓ

Soproni Egyetem Közgazdaságtudományi Kar, Sopron kulcsar.laszlo@uni-sopron.hu

OBÁdOVICS CSILlA

Soproni Egyetem Közgazdaságtudományi Kar, Sopron obadovics.csilla@uni-sopron.hu 
Ankomah, P. K.-Crompton J. L. 1992: Tourism cognitive distance. A set of research propositions. - Annals of Tourism Research 19. pp. 323-342.

BABBIE, E. 1995: A társadalomtudományi kutatás gyakorlata. - Balassi Kiadó, Budapest. 704 p.

BodRoGai L.- ViZi I. GY.-KULCSÁR L. 2017: Az örökségturizmus résztvevői és a kulturális örökség látogatóinak információforrásai a fertődi Esterházy-kastély példáján. - Tér - Gazdaság - Ember 5. 1. pp. 79-94.

Bogardus, E. S. 1925: Measuring social distances. - Journal of Applied Sociology 9. pp. 299-308.

COOK, R. L.-MCCLEARY, K. W. 1983: Redefining vacation distances in consumer minds. - Journal of Travel Research 22.2. pp. 31-34.

FAn, D. X. F.-Zhang, H. Q.-Jenkins, C. L.-Lin, P. M. C. 2016: Does social contact lessen perceived cultural distance? Evidence from tourist-host social contact. - Annals of Tourism Research 61. pp. 223-225.

Kulcsár L.-OBÁdovics Cs. 2016: Népességdinamika és társadalmi szerkezet. - Területi Statisztika 56. 4. pp. 390-414.

KuLCSÁR L.-BODROGAI L.- Vizi I. Gy. 2017: Tourism development and cultural heritage: the stakeholders'opinion on the role of the restored Esterházy Palace in Western Hungary. - Economic Thought and Practice - Ekonomska misao i praksa 26. 2. pp. 813-827.

KuLCSÁR L. 2017: A vidékfejlesztés elméleti megközelítése: Regionális és kulturális összefüggések. - Kriterion Kiadó, Kolozsvár. 228 p.

LEE, E. 1966: A theory of migration. - Demography 3. 1. pp. 47-57.

LYONS, S.-MAYOR, K.-TOL, R. S. J. 2009: Holiday destinations: Understanding the travel choices of Irish tourists. - Tourism Management 30. pp. 683-692.

Massara, F.-Severino, F. 2013: Psychological distance in the heritage experience. - Annals of Tourism Research 42. pp. 108-129.

MAtThEws, J. L.-MATLOCK, T. 2011: Understanding the link between spatial distance and social distance. - Social Psychology 42.3. pp. 185-192.

Michalkó G. 2016: Turizmológia. Elméleti alapok. - Akadémiai Kiadó, Budapest. 266 p.

NicolaU, J. L.-MÁs, F. J. 2006: The influence of distance and prices on the choice of tourist destinations: The moderating role of motivations. - Tourism Management 27. 5. pp. 982-996.

Nyaupane, G. P.-Graefe, A.-Burns R. C. 2004: Does distance matter? Differences in characteristics, behaviors, and attitudes of visitors based on travel distance. - In: MURDY, J. J. (szerk.): Proceedings of the 2003 Northeastern Recreation Research Symposium. U. S. Department of Agriculture, Bolton Landing. pp. 74-81.

PARK, R. E. 1924: The concept of social distance as applied to the study of racial attitudes and racial relations. - Journal of Applied Sociology 8. pp. 339-344.

RÁTZ T.-VIZI I. 2007: A turizmus szerepe az európai közlekedési mobilitás és integráció folyamataiban. - Földrajzi Közlemények 131.3. pp. 133-145.

WynEN, J. 2013: Explaining travel distance during same-day visits. - Tourism Management 36. pp. $133-140$. 